Журнал«Герспективита інновації наукиљ

(Серія «Гедагогіка», Серія«Гцихологія», Серія«Медицина»

№4(4) 2021

УДК : 159.9

https://doi.org/10.52058/2786-4952-2021-4(4)-410-422

Федотова Тетяна Володимирівна кандидат психологічний наук, доцент, Волинський національний університет імені Лесі Українки, вул. Потапова, 9 каб. 111, м. Луцьк, 43005, тел.: (0332) 24-90-01, e-mail: Fedotova.Tetiana@vnu.edu.ua, https://orcid.org/0000-0003-1975-9925

Кихтюк Оксана Василівна кандидат психологічний наук, доцент, Волинський національний університет імені Лесі Українки, вул. Потапова, 9 каб. 111, м. Луцьк, 43005, тел.: (0332) 24-90-01, e-mail: Kuhtuik.Oksana@vnu.edu.ua, https://orcid.org/0000-0002-8569-1896

Кульчицька Анна Валеріївна кандидат психологічний наук, доцент, Волинський національний університет імені Лесі Українки, вул. Потапова, 9 каб. 115, м. Луцьк, 43005, тел.: (0332) 24-90-01, e-mail: Kulchucka.Anna@vnu.edu.ua, https://orcid.org/0000-0003-1350-6556

\title{
ПСИХОЛОГІЧНА ПІДТРИМКА У ФОРМУВАННІ ХАРЧОВОЇ ПОВЕДІНКИ ПІДЛІТКІВ В РОБОТІ КЛІНІЧНОГО ПСИХОЛОГА
}

Анотація. В гонитві за бажанням мати ідеальні форми та образ, які культивуються масовою культурою, особистість часто забуває про власну індивідуальність та відмовляється від своєї унікальності. Особливо небезпечно відбивається наслідування нав'язаних суспільством еталонів досконалості на найуразливішій віковій групі - підлітках. У зв'язку з цим активно постає необхідність психологічної підтримки осіб підліткового віку у питаннях адекватного сприйняття власного тіла та самоставлення, а також формуванні харчової поведінки. Проблема вивчення харчової поведінки представлена у численних працях науковців-психологів, окремі аспекти цього питання зустрічаємо у дослідженнях Л. Абсалямової, Т. Вознесенської, Л. Бурлачука, В. Менделевича, І. Малкіної-Пих, В. Шебанової та інших. Проте не зважаючи на велику кількість праць, присвячених питанням харчової поведінки особистості, існує необхідність подальших напрацювань в цьому напрямку.

3 метою обгрунтування доцільності психологічної підтримки у формуванні харчової поведінки підлітків в роботі клінічного психолога, було проведене емпіричне дослідження, вибірка якого складалася зі слухачів секцій КЗ «Волинська обласна Мала академія наук», які $є$ учнями різних шкіл міста Луцька. Емпіричне дослідження передбачало реалізацію етапів: формування вибірки і підбір методик дослідження, розробку програми тренінгу; визначення груп діагностованих та типу їх харчової поведінки; проведення тренінгу та 
ретестового обстеження його учасників; аналіз та інтерпретацію результатів. У емпіричному дослідженні застосовано методики: вербальної діагностики самооцінки особистості та Голандський опитувальник харчової поведінки (DEBQ).

Результати емпіричного дослідження дозволяють констатувати наступне: проведення тренінгових занять сприяло гармонізації самооцінки підлітків (про що свідчать результати ретестового обстеження до та після проведення тренінгу); в групі підлітків із низьким рівнем самооцінки визначено певне зниження результатів за шкалами: обмежувальної харчової поведінки, емоційної харчової поведінки та екстернальної харчової поведінки; в групі підлітків із високим рівнем самооцінки спостерігаємо аналогічні тенденції, визначено статистично значущі відмінності у результатах за шкалою екстернальної харчової поведінки до та після тренінгу.

Проведене емпічрине дослідження має перспективу подальшого наукового пошуку.

Ключові слова: психологічна підтримка, харчова поведінка, обмежувальна харчова поведінка, емоційна харчова поведінка, екстернальна харчова поведінка.

Fedotova Tetiana Volodymyrivna $\mathrm{PhD}$ of Psychology, Associate Professor, Lesya Ukrainka Volyn National University, Potapova St., 9, office 111, Lutsk, 43005, tel.: (0332)24-90-01, e-mail: Fedotova.Tetiana@vnu.edu.ua, https://orcid.org/0000-0003-1975-9925

Kykhtiuk Oksana Vasylivna $\mathrm{PhD}$ of Psychology, Associate Professor, Lesya Ukrainka Volyn National University, Potapova St., 9, office 111, Lutsk, 43005, tel.: (0332)24-90-01, e-mail: Kuhtuik.Oksana@ vnu.edu.ua, https://orcid.org/0000-0002-8569-1896

Kulchytska Anna Valerijuna $\mathrm{PhD}$ of Psychology, Associate Professor, Lesya Ukrainka Volyn National University, Potapova St., 9, office 115, Lutsk, 43005, tel.: (0332)24-90-01, e-mail: Kulchucka.Anna@vnu.edu.ua, https://orcid.org/0000-0003-1350-6556

\section{PSYCHOLOGICAL SUPPORT IN THE FORMATION OF FOOD BEHAVIOR OF TEENAGERS IN THE WORK OF A CLINICAL PSYCHOLOGIST}

Abstract. In the pursuit of the desire to have ideal forms and images, which are cultivated by mass culture, the individual often forgets about his own individuality and abandons his uniqueness. It is especially dangerous to imitate the standards of excellence imposed by society on the most vulnerable age group - adolescents. In this regard, there is an active need for psychological support for adolescents in matters of adequate self-perception and self-esteem, as well as the formation of eating behavior. The problem of studying eating behavior is presented in numerous works of psychologists, some aspects of this issue are found in the studies of L. Absalyamova, T. Voznesenskaya, L. Burlachuk, V. Mendelevich, I. Malkina-Pykh, V. Shebanova and 
others. However, despite the large number of works on the eating behavior of the individual, there is a need for further work in this direction.

In order to substantiate the feasibility of psychological support in shaping the eating behavior of adolescents in the work of a clinical psychologist, an empirical study was conducted, a sample of which consisted of students of the Volyn Regional Small Academy of Sciences, who are students of different schools in Lutsk. Empirical research involved the implementation of stages: sampling and selection of research methods, development of a training program; determining the groups of diagnosed and the type of their eating behavior; conducting training and retest of its participants; analysis and interpretation of results. The empirical study used methods: verbal diagnosis of self-esteem and the Dutch Questionnaire of Food Behavior (DEBQ).

The results of the empirical study allow us to state the following: the training sessions contributed to the harmonization of adolescents' self-esteem (as evidenced by the results of the retest survey before and after the training); in the group of adolescents with a low level of self-esteem there was a certain decrease in the results on the scales: restrictive eating behavior, emotional eating behavior and external eating behavior; in the group of adolescents with a high level of self-esteem we observe similar trends, statistically significant differences in the results on the scale of external eating behavior before and after training.

The conducted empirical research has the prospect of further scientific research.

Keywords: psychological support, eating behavior, restrictive eating behavior, emotional eating behavior, external eating behavior.

Постановка проблеми. Сучасні модні тенденції та тренди диктують еталони краси та орієнтири в поведінці, манерах, стилі життя, одязі, зовнішньому вигляді та харчовій поведінці. У гонитві за ними люди прагнуть не лише наслідувати та відповідати їм, а й активно нав'язують їх своєму оточенню, обгрунтовуючи доцільність та важливість.

Бажання відповідати соціальним стандартам: 3 одного боку має свої переваги - чим дальше, тим активніше пропагується здоровий спосіб життя, здорова їжа та активний відпочинок; з іншого - «втискування» людей в певні параметри фізичного тіла, харчування та образу життя, сприяє певній невротизації людей, відмові від індивідуальності, не врахуванні індивідуальнопсихологічних особливостей особистості у взаємодії з іншими.

Прагнення мати ідеальні форми та бажаний образ, поширені у суспільстві, особливо небезпечно відображаються на дітях, зокрема, в підлітковому віці. Оскільки саме в осіб цієї вікової групи загострене сприйняття себе, свого місця в соціальному середовищі та власного тіла й доволі часто зустрічаються проблеми харчових розладів та неадекватного самоставлення. У зв'язку з цим активно постає необхідність психологічної підтримки осіб підліткового віку у питаннях адекватного сприйняття власного тіла та самоставлення, а також формуванні харчової поведінки. 
Аналіз останніх досліджень і публікацій. Останнім часом проблема вивчення харчової поведінки особистості набуває своєї актуальності, адже стосується вона не лише питання росту чи розвитку людей, а передусім покращення їх стану здоров'я, емоційного самопочуття та адаптації у складних умовах пандемії Covid-19. Різними аспектами вивчення харчової поведінки займалися $\quad$ Л. Абсалямова [1], Т. Вознесенська [2], Л. Бурлачук [3], В.Менделевич [4], Ш. Малкіна-Пих [5], В. Шебанова [6] та інші, але, не зважаючи на велику кількість праць, що стосуються дослідження цього питання, існує необхідність подальших напрацювань в даному напрямку.

Загалом згідно ієрархії потреб А. Маслоу, потреба в їжі $\epsilon$ однією 3 первинних біологічних потреб людини, яка притаманна усім живим організмам для підтримки свого існування та поповнення енергії [7]. Проте в людини споживання їжі не обмежується енергетичним поповненням свого організму життєво важливими та необхідними мікроелементами і поживними речовинами, а й характеризує ii стиль життя та досвід, соціальний статус та уподобання, національні та культурні особливості, може демонструвати певний аспект світогляду та психологічний стан особистості.

В поняття харчової поведінки вкладають ціннісне відношення до їжі та тї прийому, певний стереотип харчування в щоденних умовах та у стресових ситуаціях, поведінку, яка визначається ставленням до свого тіла (його прийняттям чи неприйняттям).

Ш. Малкіна-Пих наголошує, що харчова поведінка особистості орієнтована не лише на задоволення біологічних і фізіологічних потреб, а й на соціальнопсихологічних, у тому числі й комунікативних [8].

В стресових ситуаціях споживання їжі, як захисна реакція чи стумулювання, може полегшувати емоційні переживання особистості, знижувати дію фрустраторів, створювати ілюзію вирішення проблеми.

Також в психології виокремлюють: адекватну (яка вважається гармонійною; споживання їжі є збалансованим та раціональним) та неадекватну (їжа займає чільне місце в системі цінностей особистості - так звані гедоністи; зловживання шкідливими продуктами, ненормоване харчування чи відмова від їжі) харчову поведінку [9].

Харчова поведінка впливає на формування Я-концепції особистості, оскільки вона пов'язана зі сприйняттям фізичного образу «Я» (образу власного тіла), впливає на адекватність самооцінки особистості, ставлення до себе та певним чином визначає рівень самосвідомості.

Особливо гостро стоїть проблема формування харчової поведінки в підлітковому віці, оскільки часто-густо споживання та ставлення до їжі в осіб цієї групи далекі від адекватної харчової поведінки. Підлітки швидше схильні підпадати під вплив масової культури: часто виснажують себе різними дієтами, відмовляючись від їжі, захоплюються їжею швидкого приготування, снейками тощо. Наприклад, дівчата-підлітки відшуковують недосконалості у своїй 
Журнал«Герспектвиитаіноовації наукиљ

(Серія«Гедагогіка», Серія«Гцихологія», Серія«Медицинв»

№4(4) 2021

зовнішності, а переживання ними щастя може прямо пропорційнозалежати від їх ваги та стрункості; в гонитві за красою та ідеальною фігурою, вони можуть місяцями виснажувати себе. 3 часом такі діти не здатні бачити себе об'єктивно і тоді нав'язливі ідеї щодо ваги, образу тіла та харчування визначають їх харчові уподобання та харчову поведінку загалом: порушення харчової поведінки провокує поведінкові проблеми (замкненість, прагнення самотності, проблеми 3 адаптацією, неадекватні копінг-стратегії тощо) та порушення психічного здоров'я (розлади настрою, алекситемію, порушення самоконтролю, імпульсивність та інше).

3 дорослішанням зростає прагнення до самопізнання, тому зрозуміла посилена увага підлітків до себе, своїх особливостей, прагнення бути позитивно оціненим оточуючими та загострене самокритичне бачення свого образу. Усе вище зазначене підвищує вразливість підлітків щодо оцінок іншими, зумовлює нестабільність самооцінки, спонукає до радикальних дій стосовно себе, свого тіла, зовнішнього вигляду та інше. Критичне ставлення до себе зумовлює неприродні та саморуйнівні способи боротьби із своєю непривабливістю та може виявлятися у нервовій анорексії чи булімії [10].

Проте не всі підлітки становлять групу ризику розладів харчової поведінки, детермінантами запуску якої виступають психологічні (низька самооцінка, дезадаптація, високий рівень тривожності та невпевненість, почуття провини та інші) та соціокультурні (соціальні стереотипи та установки, релігійна приналежність, культурні традиції тощо) фактори. Саме тому психологічна підтримка підлітків в роботі клінічного психолога (як й в роботі практичного психолога освітнього закладу) повинна бути зорієнтована на: здатність обстоювати свою індивідуальність; розвиток критичності у наслідуванні соціальних стандартів та еталонів краси; прагнення до формування власної ідентичності; розвиток внутрішньої сили та впевненості; застосування конструктивних стратегій у переробці емоцій; формування адекватної самооцінки та прийняття себе і образу власного тіла.

Психологічна підтримка у формуванні адекватної харчової поведінки в осіб підліткового віку клінічним психологом, на нашу думку, полягає у індивідуальній та груповій консультативно-корекційній роботі 3 підлітками в напрямку прийняття себе, свого тіла та індивідуальних особливостей під час психологічних консультацій, зустрічей, бесід, тренінгової роботи; реалізації волонтерської, просвітницької, превентивної та профілактичної роботи.

Мета статті полягає у теоретичному вивченні психологічних аспектів харчової поведінки особистості та емпіричному обгрунтуванні ефективності психологічної підтримки у формуванні харчової поведінки підлітків в роботі клінічного психолога; 3 поставленої мети можна виокремити низку завдань: здійснити теоретичний аналіз поняття харчової поведінки; визначити особливості харчової поведінки підлітків залежно від рівня їх самооцінки; обгрунтувати ефективність психологічної підтримки у формуванні харчової 
поведінки в підлітковому віці.

Виклад основного матеріалу. 3 метою обгрунтування доцільності психологічної підтримки у формуванні адекватної харчової поведінки в підлітковому віці було проведене емпіричне дослідження, вибірка якого налічувала 60 осіб віком 14-16 років (12 хлопців та 48 дівчаток). До складу діагностованих входили слухачі секцій Комунального закладу «Волинська обласна Мала академія наук» Волинської обласної ради, які є учнями шкіл міста Луцька, а саме: Луцького навчально-виховного комплексу №9 Луцької міської ради, Луцького навчально-виховного комплексу №22 Луцької міської ради, Луцької спеціалізованої школи №1, Луцької спеціалізованої школи №5, Луцької гімназії №21 імені Михайла Кравчука, Луцької гімназії № 14 імені Василя Сухомлинського, Луцької ЗОШ I-III ступеня №7 Луцької міської ради, Луцької ЗОШ I-III ступеня № 20 Луцької міської ради.

До проведення емпіричного дослідження, в рамках проходження виробничої діагностично-консультаційної практики, були залучені студенти другого (магістерського) рівня спеціальності «Психологія» освітньо-професійної програми «Клінічна психологія» факультету психології Волинського національного університету імені Лесі Українки.

Емпіричне дослідження передбачало реалізацію наступних етапів:

$\checkmark$ на першому етапі було сформовано вибірку досліджуваних, отримано усну згоду на їх участь у тестуванні та в тренінгових заняттях;

$\checkmark$ другій етап передбачав розподіл діагностованих на групи відповідно до рівня їх самооцінки та визначення типу харчової поведінки у групах підлітків із високим, середнім та високим рівнем самооцінки;

$\checkmark$ на третій етап полягав у проведенні циклу тренінгових занять в групі діагностованих із неадекватним рівнем самооцінки та повторне їх ретестове обстеження;

$\checkmark$ четвертий етап полягав в обробці та інтерпретації результатів емпіричного дослідження.

Для проведення емпіричного дослідження було застосовано наступні методики:

-вербальну діагностику самооцінки особистості [11], яка дозволила визначити рівень самооцінки особистості: високий, середній, низький;

-Голандський опитувальник харчової поведінки (DEBQ), який дозволив 3'ясувати три важливі групи причин, через які особистість може переїдати: прагнення жорстко обмежувати себе в їжі (обмежувальна харчова поведінка); звичка заїдати емоції (емоціогенна харчова поведінка); нездатність встояти перед смачною їжею/ароматом/виглядом (екстернальна харчова поведінка).

В результаті проведення методики вербальної самооцінки особистості було виокремлено наступні групи підлітків: група 1 - підлітки 3 низьким рівнем самооцінки (10\% осіб); група 2 - діти із середнім рівнем самооцінки (74\% дітей); група 3 - школярі із високим рівнем самооцінки (16\% осіб). 
Журнал«Герспективитаінновації науки

(Серія«Гедагогіка», Серія«ГЕихологія», Серія«Медицина»

№4(4) 2021

В результаті обчислень однофакторного дисперсійного аналізу було визначено статистично значущі відмінності у результатах самооцінки в діагностованих усіх трьох груп ( $\mathrm{F}=6,18$, при $\alpha \leq 0,01)$.

Кількісний розподіл усіх діагностованих за шкалами методики Голандського опитувальника харчової поведінки (DEBQ) зображено на рис. 1 .

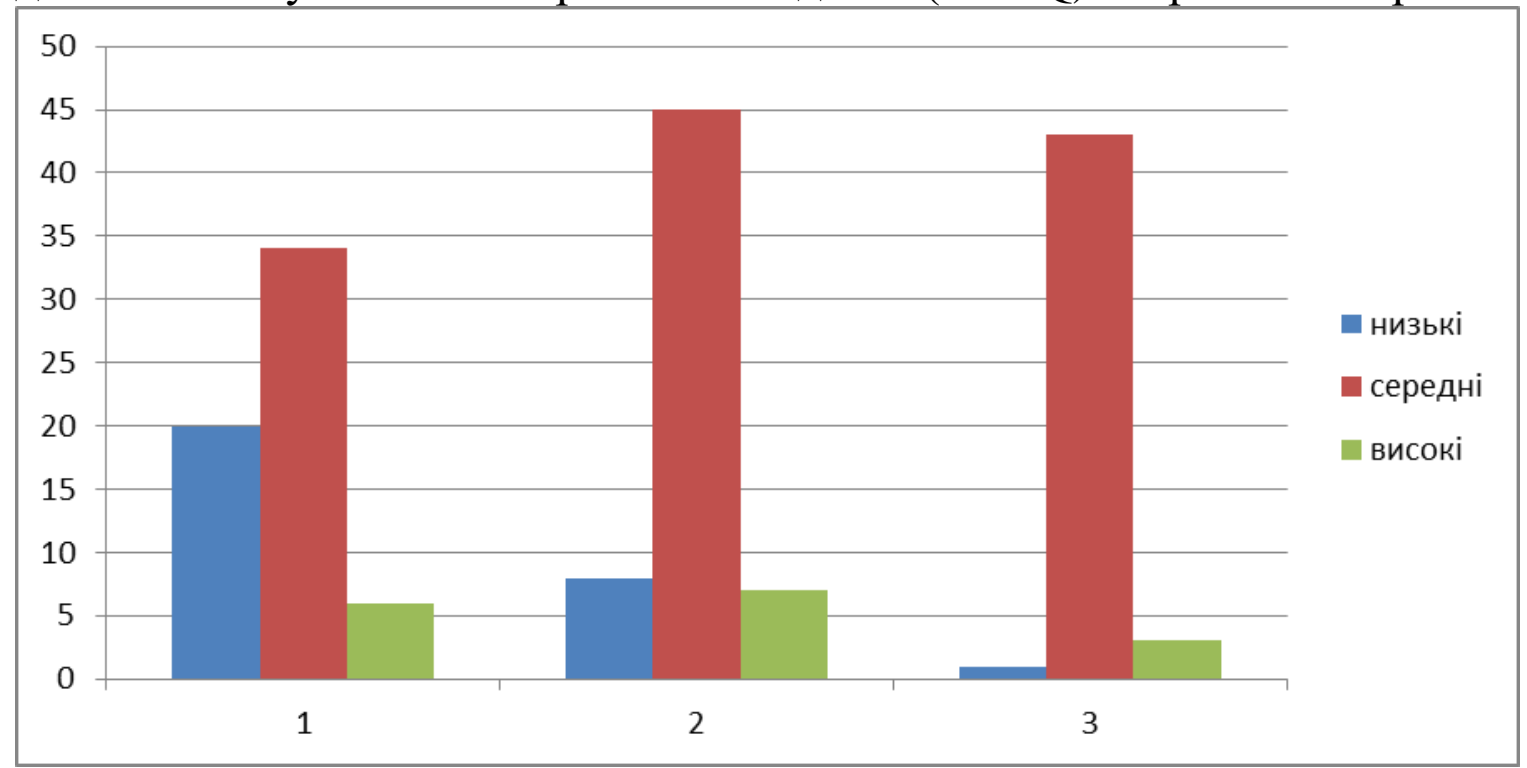

Pис.1. Розподіл усіх діагностованих підлітків за шкалами методики Голандського опитувальника харчової поведінки (DEBQ)

Примітка: 1 - обмежувальна харчова поведінка; 2 - емоційна харчова поведінка;

$$
3 \text { - екстернальна харчова поведінка }
$$

Отже, як засвідчує рис.1 в діагностованих підлітків усієї вибіркової сукупності визначено:

$>$ за шкалою обмежувальної поведінки - у 34 осіб середні результати (при нормі 2,4), 20 підлітків мають низькі показники та у 6 дітей спостерігаємо виражену обмежувальну харчову поведінку, тобто вони суворо контролюють свій раціон харчування та часто дотримуються дієти;

$>$ за шкалою емоційної харчової поведінки: 7 дітей демонструють емоціогенну харчову поведінку, тобто схильні «заїдати» стрес, напруження, хвилювання тощо; у 45 підлітків - констатовано середні показники (при нормі 1,8); 8 школярів - вирізняються низькими результатами за цією шкалою;

$>$ за шкалою екстернальної харчової поведінки: 16 підлітків мають високі показники, тобто обираючи їжу, вони орієнтуються за смакові, нюхові, зорові відчуття; їжа для них, як додаток до спілкування 3 однолітками, друзями, родиною; 45 осіб - демонструють показники в межах норми - 2,7; одна дитина була визначена із низьким результатом за цією шкалою.

Усереднені результати діагностованих трьох груп за шкалами методики Голандського опитувальника харчової поведінки (DEBQ) зображено на рис.2. 


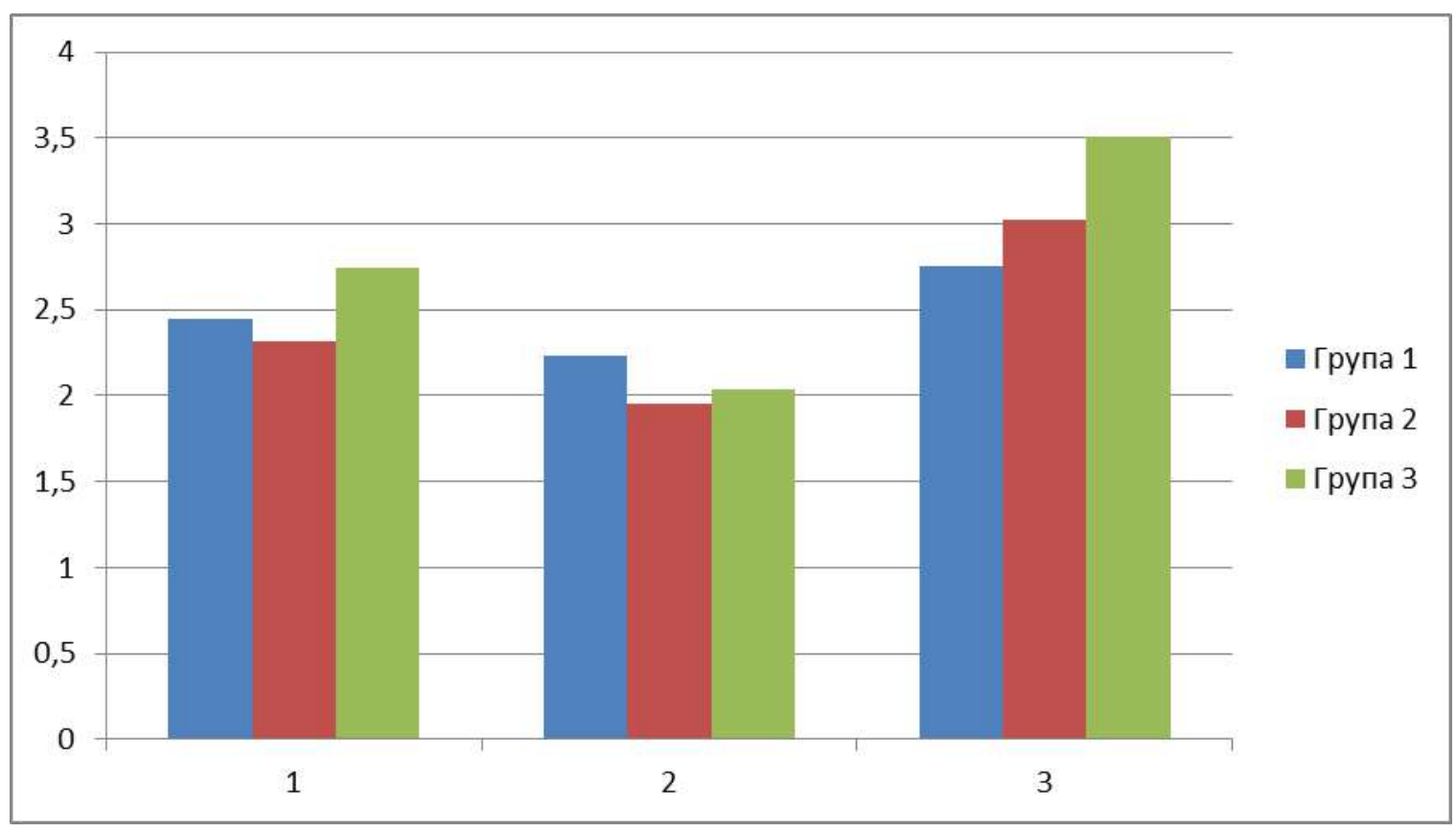

Puс.2. Середньогрупові результати діагностованих із різним рівнем самооиінки за шкалами методики Голандського опитувальника харчової поведінки (DEBQ)

Примітка: 1 - обмежувальна харчова поведінка; 2 - емоційна харчова поведінка; 3 - екстернальна харчова поведінка

Отже, на рис.2. ми можемо побачити відмінності у середньогрупових результатах підлітків трьох груп:

найвищі показники 3-поміж трьох груп було визначено у підлітків третьої групи (підлітки 3 високим рівнем самооцінки) за шкалами:

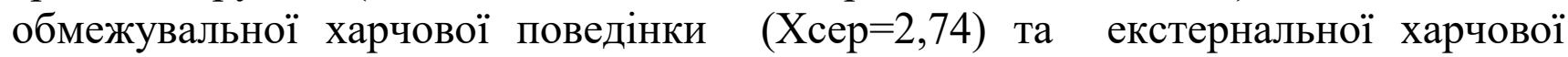

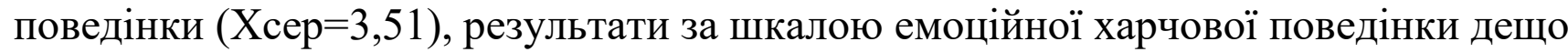
перевищують показники норми (X сер=2,04);

за шкалою емоційної харчової поведінки найвищий показник було визначено у підлітків першої групи (підлітки з низьким рівнем самооцінки) (Хсер=2,23); решта шкал теж дещо перевищують показники норми: обмежувальна харчової поведінки - Хсер=2,45 та екстернальної харчової поведінки - Хсер=2,75;

результати підлітків із середнім рівнем самооцінки (Група 2) хоча й знаходяться в межах середніх результатів усіх діагностованих груп, проте теж $\epsilon$ дещо вищими за середні норми методики: обмежувальна харчова поведінка -

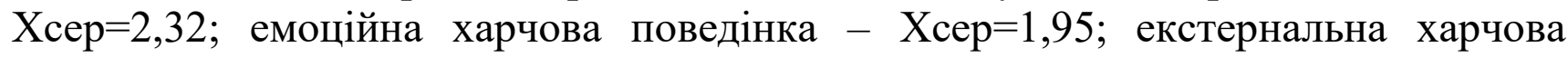
поведінка - Хсер=3,13.

Тобто усім діагностованим підліткам складно переробляти емоції, не вдаючись до їжі, вони схильні в стресових ситуаціях вдаватися до їжі, «заїдати» невпевненість, тривожність та інші негативні емоції. До того ж підлітки із 
Журнал«Герспективита іновації науки»

(Серія«Гедагогіка», Серія «Гцихологія», Серія«Медицина»

№4(4) 2021

середнім та високим рівнем самооцінки легко піддаються спокусі при вигляді смачної іжі, схильні переїдати в компанії.

Завдяки однофакторному дисперсійному аналізу було визначено статистично значущі відмінності в результатах діагностованих першої та третьої групи за шкалою екстернальної харчової поведінки $(\mathrm{F}=6,84$, при $\alpha \leq 0,01)$.

Для того, щоб обгрунтувати дієвість психологічної підтримки клінічним психологом осіб підліткового віку щодо формування в них адекватної харчової поведінки, підліткам із завищеною та низькою самооцінкою було запропоновано взяти участь у тренінгу особистісного зростання. Оскільки саме в дітей 3 цих груп діагностованих було виявлено схильність вдаватися до неадекватних способів переробки емоційно складних ситуацій («заїдання» проблем чи відмова від їжі, інколи неможливість контролювати їі споживання, переїдання під час спільного споживання їжі тощо).

Психологічний тренінг складався із десяти занять по дві години кожне. До тренінгової групи увійшло 15 підлітків (6 осіб із низьким рівнем самооцінки та 9 - із високим рівнем).

Під час тренінгових зустрічей, окрім завдання формування адекватної харчової поведінки в підлітковому віці, було виокремлено ще низку таких завдань: активізація процесу самопізнання; навчання різним технікам саморегуляції емоційного стану; формування адекватної самооцінки та позитивного ставлення до себе й своїх можливостей. Перші два заняття були спрямовані на знайомство та створення сприятливої психологічної атмосфери в групі; наступні дві зустрічі передбачали діагностику та усвідомлення власної проблеми учасниками Т-групи; решта п'ять занять були присвячені реалізації корекційної програми та останнє заняття полягало у підведенні підсумків тренінгу. Під час тренінгових занять було дотримано всі принципи та правила проведення психологічного тренінгу.

Через місяць після проведеного тренінгу, з його учасниками було проведене ретестове дослідження, яке передбачало повторну фіксацію результатів за методиками: вербальної діагностики самооцінки особистості та Голандським опитувальником харчової поведінки (DEBQ).

Показники за методикою вербальної самооцінки особистості, отримані після проведення тренінгу, дозволили констатувати тенденцію в нормалізації рівня самооцінки, тобто зменшення відсотку підлітків із неадекватним iї рівнем (рис.3). 


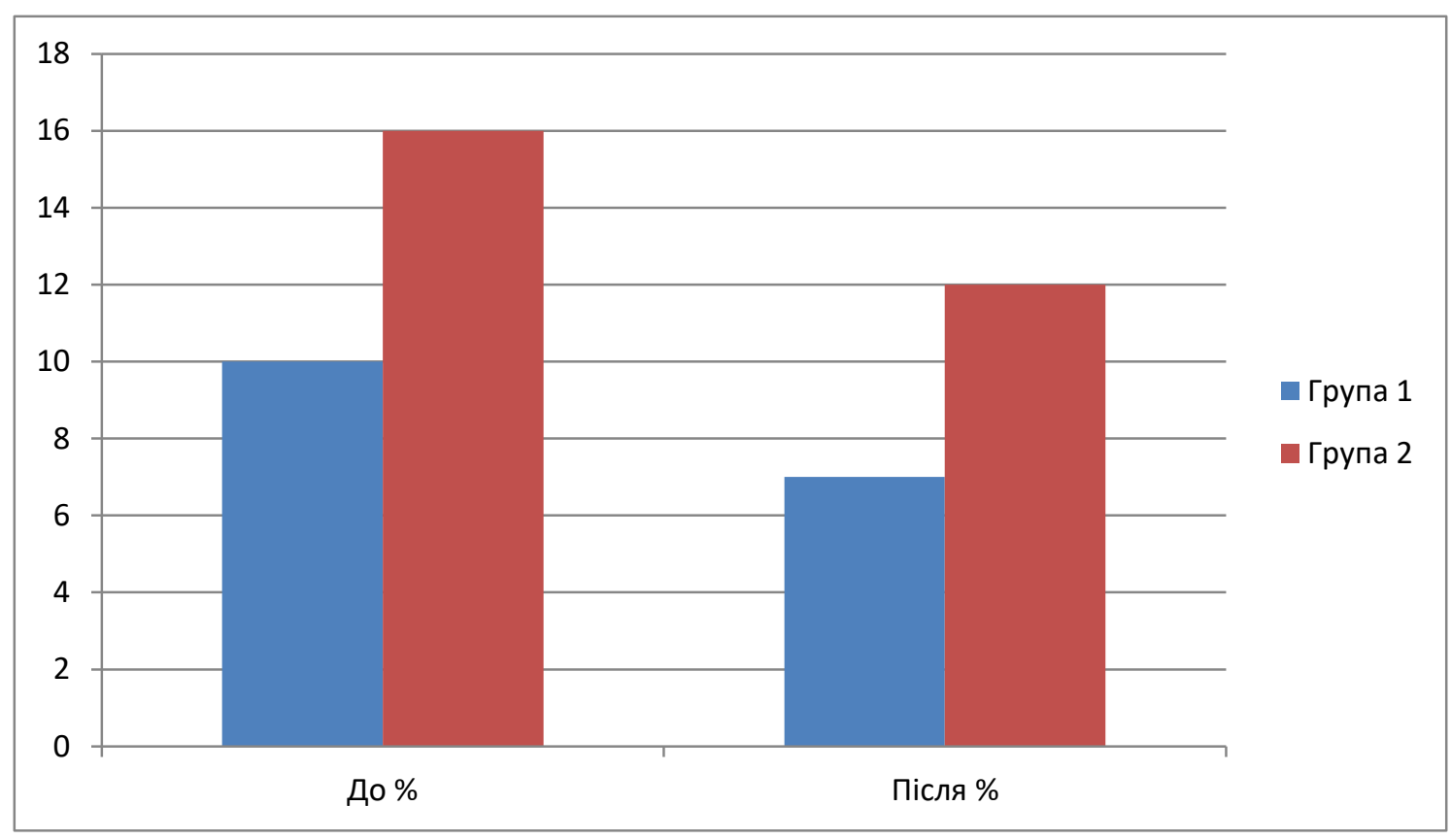

Pис.3 Відсотковий розподіл діагностованих за методикою вербальної самооцінки особистості до і після проведення тренінгу

На рис.3 можемо бачити, як зменшився відсоток підлітків із неадекватним рівнем самооцінки:

- до проведення тренінгу було визначено $10 \%$ підлітків із низьким рівнем самооцінки та 16\% школярів - із високим ii рівнем самооцінки;

- після тренінгу відсотковий розподіл виявився таким: 7\% підлітків із низьким рівнем самооцінки та $12 \%$ школярів - із високим ii рівнем самооцінки

Тобто корекційні заняття тренінгу сприяли формуванню адекватнішого ставлення до себе та оцінки власних індивідуальних особливостей. Причому ми спостерігали не лише кількісно-відсоткове зменшення осіб із неадекватним рівнем самооцінки, а й зменшення усереднених результатів діагностованих підлітків двох груп. Хоча й статистично значущих відмінностей у показниках самооцінки в діагностованих обох груп до та після тренінгу визначено не було.

Порівняння результатів за шкалами методики Голандського опитувальника харчової поведінки (DEBQ) до та після проведення тренінгу в двох групах діагностованих подано у таблицях 1-2. 
Журнал«Герспективитаінновації наукиљ

(Серія«Гедагогіка», Серія«ГЕихологія», Серія«Медицина»

№4(4) 2021

Таблиияя 1.

\section{Середньогрупові результати}

підлітків із низькимим рівнем самооцінки за методикою Голандського опитувальника харчової поведінки (DEBQ) $(\mathbf{n}=6)$

\begin{tabular}{|c|c|c|c|}
\hline & До тренінгу & Після тренінгу & $\begin{array}{c}\text { F- } \\
\text { критичне }\end{array}$ \\
\hline $\begin{array}{c}\text { обмежувальна харчова } \\
\text { поведінка }\end{array}$ & 2,45 & 2,23 & 1,02 \\
\hline емоційна харчова поведінка & 2,23 & 1,94 & 1,34 \\
\hline $\begin{array}{c}\text { екстернальна харчова } \\
\text { поведінка }\end{array}$ & 2,75 & 2,71 & 0,98 \\
\hline
\end{tabular}

Табличя 2.

Середньогрупові результати

підлітків із високим рівнем самооцінки за шкалами методики

Голандського опитувальника харчової поведінки (DEBQ) (n=9)

\begin{tabular}{|c|c|c|c|}
\hline & До тренінгу & Після тренінгу & $\begin{array}{c}\text { F- } \\
\text { критичне }\end{array}$ \\
\hline $\begin{array}{c}\text { обмежувальна харчова } \\
\text { поведінка }\end{array}$ & 2,74 & 2,57 & 3,14 \\
\hline емоційна харчова поведінка & 2,04 & 1,92 & 0,89 \\
\hline $\begin{array}{c}\text { екстернальна харчова } \\
\text { поведінка }\end{array}$ & 3,51 & 2,93 & $4,2 *$ \\
\hline
\end{tabular}

Примітка: * при $\alpha \leq 0,05$

Отже, хоча в групі підлітків із низьким рівнем самооцінки й не було визначено статистично значущих відмінностей у показниках за методикою Голандського опитувальника харчової поведінки (DEBQ), проте можемо констатувати певне зменшення середньогрупових результатів за усіма шкалами. Тобто, якщо до тренінгу вони лише вдавалися до стратегії «заїдання проблем», зверталися до їжі в емоційно напружених ситуаціях (невпевненості та тривоги), то в результаті участі в корекційних заняттях психологічного тренінгу, вони засвоїли нові способи опанування стресових ситуацій (наприклад, застосовуючи техніку «Рефреймінгу» тощо).

Аналогічні тенденції спостерігаємо в групі підлітків із високим рівнем самооцінки. В них було визначено статистично значущі відмінності у результатах за шкалою екстернальної харчової поведінки до та після тренінгу. Тобто відповідні особи підліткового віку не тільки здобули навички альтернативного конструктивного пропрацювання емоційно напружених ситуацій, усвідомили небезпеку надмірного захоплення дієтами та зрозуміли красу власного тіла, а й почали надавати перевагу раціональному харчуванню; зменшили кількість споживання їжі під час спілкування 3 друзями, звертаючи 
увагу на інші аспекти міжособистісної взаємодії, в них з'явилося прагнутьустановка харчуватися розумно.

Висновки. Отже, харчова поведінка визначається індивідуальними особливостями та нахилами, культурною, етнічною та релігійною приналежністю людини; вона зумовлює уподобання, цінності, поведінкові копінг-стратегії та установки особистості. Харчова поведінка певним чином дозволяє сформувати психологічний портрет особистості, визначити внутрішньо особистісні конфлікти, наявні комплекси та помилкові переконання. Найгостріше проблема формування харчової поведінки постає в підлітковому віці, оскільки їх схильність слідувати модним трендам та захоплення відомими людьми/кумирами, часто спонукають до розладів харчової поведінки.

Результати емпіричного дослідження засвідчують важливість та ефективність психологічної підтримки у формуванні харчової поведінки підлітків в роботі психолога, передусім клінічного психолога, оскільки найчастіше саме фахівець цієї спеціалізації стикається 3 розладами харчової поведінки особистості.

Перспективу подальшого наукового пошуку вбачаємо у розширенні арсеналу методик та вибірки досліджуваних у вивченні харчової поведінки підлітків, а також визначення специфіки психологічної підтримки у формуванні харчової поведінки осіб цієї вікової групи з урахуванням гендерного аспекту.

\section{Лimepamypa:}

1. Абсалямова Л. М. Психологія харчової поведінки людини. Навчально-методичний посібник. Харків: Видавництво «Смугаста типографія», 2017. 181 с.

2. Вознесенская Т. Г. Расстройства пищевого поведения при ожирении и их коррекция. Фармак, 2009. №12. С.91-94.

3. Бурлачук Л. Ф.. Шебанова В. І. Локус каузальності як фактор трансформації внутрішньої картини життєдіяльності особистості 3 розладами харчової поведінки. Науковий часопис Національного педагогічного університету імені М. П. Драгоманова. Серія 12. Психологічні науки: Зб. наук. праць. Київ: НПУ імені М. П. Драгоманова. 2015.№1(46). С. 53-66.

4. Менделевич В. Д. Клиническая и медицинская психология. Москва: Мед Пресс-информ, 2005. 468 с.

5. Малкина-Пых И. Г. Терапия пищевого поведения. Москва: Эксмо, 2007. 1040 с.

6. Шебанова В. І. Харчова поведінка в структурі тілесності: теоретичні й методологічні основи тілесності [Електронний ресурс]. Науковий вісник Херсонського державного університету. Серія: Психологічні науки. Херсон, 2014. Вип. 1(2). С. 186-192.

7. Маслоу А. Дальние пределы человеческой психики. Санкт-Перербург. «Евразия», 1997. $430 \mathrm{c}$.

8. Малкина-Пых И. Г. Терапия пищевого поведения. Москва: Эксмо, 2007. 1040 с.

9. Вахмістров А. В. Нарушения пищевого поведения при церебральном ожирении: Автореф. дис. ... канд. мед. Наук. СПб., 2006. 24 с.

10. Федотова Т. В., Кульчицька А. В. Соціально-психологічні аспекти формування харчової поведінки в підлітковому віці. Психологічні перспективи. Випуск 33. Луцьк : СНУ імені Лесі Українки, 2019. С. 178-204.

11. Фетискин Н. П., Козлов В. В., Мануйлов Г. М. Социально-психологическая диагностика развития личности и малых групп. М., Изд-во Института Психотерапии. 2005. 490 с. 


\section{References:}

1. Absalyamova, L. M. (2017). Psyhologiya harchovoyi povedinky lyudyny [Psychology of human eating behavior.]. Harkiv: Vidavnycztvo «Smugasta tipografiya» [in Ukrainian]

2. Voznesenskaya, T. G. (2009). Rasstrojstva pishevogo povedeniya pri ozhirenii i ih korrekciya [Eating disorders in obesity and their correction]. Farmak - Farmak, 12, 91-94. [in Russian]

3. Burlachuk, L. F.. Shebanova, V. I. (2015). Lokus kauzalnosti yak faktor transformaciyi vnutrishnoyi kartyny zhettyediyalnosti osobystosti z rozladamy harchovoyi povedinky [Locus of causality as a factor in the transformation of the internal picture of the individual with eating disorders]. Naukovyj chasopys Nacionalnogo pedagogichnogo universytetu imeni M. P. Dragomanova. Seriya 12. Psyhologichni nauky - Scientific journal of the National Pedagogical University named after MP Drahomanov. Series 12. Psychological Sciences, 1(46), 53-66. [in Ukrainian]

4. Mendelevich, V. D. (2005). Klinicheskaya i medicinskaya psihologiya [Clinical and medical psychology]. Moskva: Med Press-inform [in Russian]

5. Malkina-Pyh, I. G. (2007). Terapiya pishevogo povedeniya [Therapy of eating behavior]. Moskva: Eksmo [in Russian]

6. Shebanova, V. I.(2014). Harchova povedinka v strukturi tilesnosti: teoretychni j metodologichni osnovy tilesnosti [Food behavior in the structure of corporeality: theoretical and methodological foundations of corporeality]. Naukovyj visnik Hersonskogo derzhavnogo universytetu. Seriya: Psyhologichni nauky - Scientific Bulletin of Kherson State University. Series: Psychological Sciences, 1(2), 186-192. [in Ukrainian]

7. Maslou, A. (1997). Dalnie predely chelovecheskoj psihiki [Far limits of the human psyche]. Sankt-Pererburg. «Evraziya» [in Russian]

8. Malkina-Pyh, I. G. (2007). Terapiya pishevogo povedeniya [Therapy of eating behavior]. Moskva: Eksmo [in Russian]

9. Vahmistrov, A.V. (2006). Narusheniya pishevogo povedeniya pri ce- rebralnom ozhirenii [Eating disorders in obesity and their correction]. Extended abstract of candidate's thesis. SPb.: $\mathrm{SPb}$. [in in Russian].

10. Fedotova, T. V., Kulchytska, A. V. (019). Socialno-psyhologichni aspekty formuvannya harchovoyi povedinky $\mathrm{v}$ pidlitkovomu vici [Socio-psychological aspects of the formation of eating behavior in adolescenc]. Psyhologichni perspektyvy - Psychological perspectives, 33. 178-204. [in Ukrainian]

11. Fetiskin, N. P., Kozlov, V. V., Manujlov, G. M. (2005). Socialno-psihologicheskaya diagnostika razvitiya lichnosti $i$ malyh grupp [Socio-psychological diagnosis of personality development and small group]. M., Izd-vo Instituta Psihoterapii [in Russian] 